\title{
60 till 70-åringars tal om den egna alkoholkonsumtionen
}

\author{
KAJSA BILLINGER
}

\begin{abstract}
Åldersgruppen som föddes på fyrtiotalet har sett stora förändringar $i$ alkoholpolitiken och $i$ synen på alkohol. I denna studie undersöks hur personer $i$ denna åldersgrupp resonerar om sitt förhållande till alkohol, hur de ser på gränserna mellan vad som är ett acceptabelt och ett oacceptabelt drickande.
\end{abstract}

\section{Inledning}

De äldre i befolkningen har tidigare druckit mindre alkohol än de yngre, men de som nu går i pension har en betydligt högre alkoholkonsumtion jämfört med tidigare generationer. Särskilt äldre kvinnor tycks ha ökat sin konsumtion. Socialtstyrelsen har i sin Lägesrapport (2012) tittat närmare på utveckling för män och kvinnor åldersgruppen 60-79 år och funnit att antalet personer som vårdats i slutenvård med diagnosen alkoholdiagnos har ökat med 45 procent under perioden 2000-2010. Allt fler äldre dör med en alkoholrelaterad diagnos. Dödligheten har ökat mest dramatiskt för män i åldersgruppen 60-69 år (Socialstyrelsen 2012).

Kajsa Billinger, universitetslektor, institutionen för socialt arbete Stockholms universitet.
Den ökande konsumtionen bland äldre är inte enbart ett svenskt fenomen utan gäller hela västvärlden. I en amerikansk studie från 2005 med personer i åldrarna 25 till 74 år konstateras att individers alkoholkonsumtion visserligen avtar med stigande ålder men att konsumtionen avtar $\mathrm{i}$ lägre grad i de senare kohorterna. Detta är en indikator på den effekt fyrtiotalistgenerationen kan komma att få på alkoholkonsumtionen bland äldre (Moore et al. 2005; Blazer \& Wu 2009).

De förändrade alkoholvanorna bland äldre kan hänföras till det fysiska åldrandet, till den kohort man ingår i och/eller i vilken tidsperiod man befinner sig i (Jung 2010), men även till den enskilda individens uppfattning om den egna identiteten. De stora åldersgrupper som föddes $i$ Sverige på fyrtiotalet och som nu har gått i pension eller som närmar sig pensionsål- 
dern, har sett stora förändringar i alkoholpolitiken. De som idag är mellan 60 och 70 år tillhör en generation vars föräldrar växte upp under nykterhetsrörelsens storhetstid, och själva har de vuxit upp under en tid med en restriktiv alkoholpolitik. Det centrala inslaget har varit att staten haft monopol på all hantering av alkohol, till en situation idag, när staten enbart har detaljmonopolet kvar och alkoholkonsumtionen alltmer har blivit en vardagsföreteelse. De har levt sitt vuxenliv i en era av expanderande alkoholvanor.

Tidigare generationer har minskat sin alkoholkonsumtion när de blivit äldre, men hur formar de som tillhör fyrtiotalistgenerationen sina liv i förhållande till alkoholen? Denna grupp representerar ofta andra levnadssätt, livsstilar och konsumtionsvanor än de som tidigare varit rådande bland de äldre (Valkonen \& Kauppinen 2005). Alkoholbruket i den äldre delen av befolkningen kommer med stor säkerhet att spela en större och mer synlig roll än i tidigare generationer, vilket kommer att påverka såväl enskilda individer som samhället i stort.

\section{Några utgångspunkter och syfte}

Förändringar i alkoholkonsumtionen över tid påverkas av alkoholpolitik och också av synen på alkohol. Idag nås vi av budskap som gör gällande att ett glas rödvin om dagen är bra för hälsan samt att alkohol kan vara en del av en angenäm "tredje ålder". Bruket av alkohol har blivit ett sätt att uttrycka sin identitet och livsstil. En utgångspunkt i denna studie är antagandet om att det finns en koppling mellan människors berättelser och deras identitet eller personlighet (Lieblich et al. 2008). Fasta normer och värden grundade i tillhörigheten till en grupp, klass eller bygemenskap, har i allt större utsträckning blivit tillgängliga för överväganden och individuella val. Dessa individuella val uppstår dock inte i ett vakuum, våra beslut och värderingar är sociala produkter. I den socialt konstruktionistiska synen på människan skapas och omskapas hon kontinuerligt genom samspelet med andra människor och genom sociala och kulturella aktiviteter (Wetherell \& Maybin 1998). För att studera förändringar i konsumtion över tid, kan ett sätt vara att studera det som händer $\mathrm{i}$ interaktionen mellan aktörerna, vad 60 till 70 åringar säger om sina alkoholvanor i samtal med varandra (Elster \& Skog 1999). Genom att öka kunskapen om alkoholens roll i identitetskapandet ökas möjligheten att också få veta mer om hur problem uppstår.

Syfte med föreliggande studie är att undersöka hur personer i Sverige - som idag lever i den tredje åldern - tillsammans resonerar om sitt förhållande till alkohol, hur de ser på gränserna mellan vad som är ett acceptabelt och oacceptabelt drickande. Den centrala frågeställningen är: Hur beskriver dessa 60-70 åringar sina erfarenheter av alkoholkonsumtion och vilken betydelse har alkoholen i deras liv? Frågeställningen konkretiseras via delfrågor som: Vad ses som ett kulturellt acceptabelt sätt att använda alkohol på och vad är inte acceptabelt? Vilka problem ser de med alkohol? Vilka överväganden gör de för egen del? Hur ser de på sig själva?

Studien är finansierad av Centrum 
för kompetensutveckling inom vård och omsorg (CKVO), Stockholms universitet.

\section{Angränsande forskning om äldre och alkohol}

Det finns några studier, de flesta från Finland, där utgångspunkten är att både åldrandet och alkoholbruket påverkas av historiska, sociala och kulturella faktorer. Syftet med Eija Tolvanens (1998) studie var att utreda om de nu rådande kulturella dryckesvanorna inverkar på hur äldre finländare talar om sitt alkoholbruk. Materialet bestod av intervjuer med finländare som var födda år 1900, de var alltså betydligt äldre än deltagarna i föreliggande studie. Materialet härstammar från en uppföljningsundersökning där avsikten var att utreda äldre personers levnadsförhållanden i Tammerfors. Bland de äldre kunde man urskilja fyra olika sätt att definiera sitt eget alkoholbruk. De intervjuade indelades i helnyktra, de som upphört att använda alkohol, de som drack beroende på situation och de som drack måttligt. Alkoholbruket beskrevs närmast som en del av vardagen och de kulturella ramarna och utgick inte från åldrandet. Studien visade att åldrandet inte längre är en skild faktor som i sig bestämmer en människas levnadsvanor, det postmoderna åldrandet består av mångfacetterade och individuella element.

Syftet med en annan studie (Tolvanen \& Jylhä 2005) var att undersöka hur 90 åriga finländare strukturerar sina livsberättelser som handlar om deras alkoholbruk. Huvudfrågorna i studien var: Hur beskriver de äldsta finländarna sitt alkoholbruk inom ramen för en biografisk intervju? Hur karakteriserar de intervjuade sig själva och sitt förhållande till alkoholen? Vilka slags retoriska medel använder de intervjuade i sina karakteristiker? Som material användes biografiska intervjuer och syftet var att synliggöra olika kulturella tolkningsrepertoarer i anslutning till alkoholbruket. Analysen gav fyra tolkningsrepertoarer beroende på hur de gamla talade om alkohol: en moralistisk repertoar, en repertoar präglad av öde och hot, en benämnd det sociala deltagandets repertoar samt en hälsorepertoar. De äldres synpunkter framstod ofta som ett motsatsförhållande mellan två verkligheter, där de egna måttliga och ansvarsfulla dryckesvanorna klart åtskildes från "andras" storkonsumtion och problembruk.

I en svensk studie (Abrahamson 2009) var syftet att undersöka hur personer presenterar sig själva, sina värderingar och sitt förhållningssätt till alkohol i nedskrivna livshistorier. Nordiska museet har sedan 1920-talet, för att dokumentera svenskt vardagsliv, skickat frågelistor om olika spörsmål till utvalda så kallande meddelare och 2007 var rubriken "Alkoholen i mitt liv". Studiens urval består av meddelare som är födda mellan 1914 och 1930, totalt 31 bidrag, 26 kvinnor och 5 män. Resultatet blottlade två diskursiva repertoarer: Nykterhetens repertoar och Måttlighetens repertoar. Inom nykterhetens repertoar var alkoholen viktig och nykterheten var en viktig princip för hur livet organiserades. I måttlighetens repertoar däremot presenterades alkoholen som naturlig och oviktig. Den sociala samvaron var alkoholens rätta plats i båda repertoarerna. I nykterhetens 
repertoar var det viktigt att visa sin nykterhet på ett sådant sätt att det inte generade människorna i sammanhanget, den sociala samvarons primära syfte var att människor ska trivas och ge en känsla av gemenskap. I måttlighetens repertoar var det centralt att delta i det sociala drickandet utan att visa sig berusad och också visa att de egentligen inte behövde alkoholen. Trots att båda repertoarerna var fyllda med moraliska värderingar kring rätt och fel, karaktäriserades båda av avsaknaden av fördömanden av andra människors alkoholvanor, med undantag för ungdomars dryckesvanor.

I en studie, som baserades på intervjuer med 60-70 åringar som bodde $i$ finska städer (Haarni \& Hautamäki 2010), beskrivs dryckesvanorna och de äldres relation till alkohol. I artikeln hävdas att både händelser i de intervjuades liv och förändringar i den finska alkoholkulturen har format dagens dryckesvanor hos de äldre. De intervjuades dryckesvanor och den betydelse man gav alkoholkonsumtionen varierade i många avseenden. Det var dock vanligt att de äldre drack varje dag, liksom i hela befolkningen i Finland är alkohol mer vanligt förekommande än tidigare. Dock hade den stora majoriteten av de äldre med åren lärt sig att handskas med alkohol, de hade lärt sig att kontrollera sin konsumtion och undvika berusning. Färdigheten att konsumera alkohol med måtta hade utvecklats med åren.

De äldres egna förklaringar till sin alkoholkonsumtion undersöktes i en studie i Finland (Immonen et al. 2011). En enkät skickades till 2100 slumpmässigt utvalda personer över 65 år som bodde i en medelstor stad. De som angav att de använde alkohol angav följande förklaringar till sitt drickande: "för att ha roligt eller för att fira" (59 procent), "av sociala skäl" (54 procent), "använder alkohol av medicinska skäl" (20 procent) samt "till maten" (14 procent). Sammantaget visade studien att äldre har olika förklaringar till sin alkoholkonsumtion likt personer i andra åldersgrupper, att de allra äldsta använde alkohol i medicinskt syfte och att de med riskkonsumtion använde alkohol på grund av meningslöst liv och för att motverka depression, ångest och ensamhet.

\section{Metod}

Den här studien bygger på fokusgruppsintervjuer som är en form av gruppintervju där deltagarna diskuterar ett givet ämne med stöd i en diskussionsguide. Grundtanken är att deltagarna i interaktion delger perspektiv på det aktuella ämnet som handlar om kulturella skeenden. Dynamiken i fokusgrupper formar och fångar sådana skeenden, vilket inte en individuell intervju gör. En utgångspunkt för att använda material från fokusgrupper är att det sätt på vilket vi uppfattar användning av alkohol är socialt konstruerat av sociala aktörer i ett socialt meningsbärande sammanhang (Billinger 2000; Kaskutas et al. 2000).

Fyra fokusgrupper har genomförts. Då kön, ålder, bostadsortens storlek och inkomsten har betydelse för synen på alkohol (Hübner, 2009), rekryterades de fyra grupperna utifrån tanken att de skulle representera olika grupper av befolkningen. Två grupper bestod av kvinnor och två av män. Den ena kvinnogruppen bestod av 
kvinnor som bodde på landsbygden och som hade utbildning på gymnasienivå (KL) och den andra av kvinnor som bodde i storstadsområde och som hade högskoleutbildning (KS). De två mansgrupperna hade samma kriterier (ML resp. MS).

Deltagarna till respektive grupp rekryterades genom att en person som uppfyllde kriterierna tillfrågades om hon eller han hade förslag på ytterligare deltagare. Tanken var att deltagarna i redan existerande och homogena grupper deltar mer aktivt i samtalen, att samtalen blir så kulturbärande som möjligt. Intervjuguiden ${ }^{1}$ bestod av fyra delar. I den första delen ombads deltagarna att berätta om hur de som barn eller unga kom i kontakt med alkohol eller blev medvetna om att alkohol fanns. I den andra delen visades 16 olika bilder för deltagarna, bilder som föreställde människor i olika åldrar och sammanhang och där alkohol fanns med i bilden. De flesta bilderna är desamma som använts i studien varifrån intervjuguiden är hämtad. Några bilder har bytts ut och ersatts med ett par bilder på äldre personen och ett par bilder där barn finns med. I föreliggande studie har deltagarnas utsagor kring bilderna inte varit föremål för djupare analys, utan mer fungerat som stimuli. Uppgiften var att fundera över egna erfarenheter av alkohol utifrån vad bilderna visade. I den tredje delen ställdes frågor om hur delta-

1 Intervjuguiden är densamma som konstruerats av professor Jukka Törrönen, Centrum för socialvetenskaplig alkohol- och drogforskning (SoRAD), och som använts i ett liknande projekt men med fokus på lägre åldersgrupper (Tigerstedt et al. 2010). garna använde alkohol nu för tiden, vad som var en lyckad eller misslyckad dryckessituation, berusningens betydelse och en typisk dryckessituation. Slutligen i den sista delen ställdes frågor om deras avsikt med att dricka hade förändrats över tid och om de tyckte att det skett förändringar i drickandet hos pojkar och flickor och män och kvinnor, jämfört med hur det var i deras barndom. Intervjuerna utfördes av författaren som sedan noggrant läst igenom det transkriberade materialet. Sammanfattningar av deltagarnas uttalanden gjordes och de strukturerades efter fem teman som redovisas i resultatdelen. Resultatredovisningen är relativt omfattande, detta för att läsaren ska kunna bedöma resultatet (Lieblich et al. 1998). För att finna bärande element, begrepp och mönster $\mathrm{i}$ deltagarnas samtal, var det nödvändigt att göra olika bedömningar och avvägningar. I de gemensamt producerade samtalen sökte jag efter vad deltagarna fann värt att tala om, och hur det värderades. Jag sökte efter den underliggande poängen, den som kan sägas frilägga de implicita värdesystem som förknippas med den kulturella innebörden (Adelswärd 1997).

Analysen har gjorts i två steg, i linje med den hermeneutiska tolkningen (Kvale \& Brinkman 2009). I det första steget görs en tolkning efter varje tema och i det andra görs en tolkning av helheten och dess relation till tidigare forskning. För att tydliggöra det konstruktivistiska perspektivet används ett dialektiskt angreppssätt där motsatsförhållanden mellan olika uttalanden lyfts fram under respektive tema.

Analysen kan sägas tillhöra den kategori som Lieblich et al. (1998) benämner 
categorical-content reading, en strategi som tar fasta på innehållet, vad som sägs och vad som menas, snarare än form och struktur. I resultatredovisningen anges vilken av fokusgrupperna uttalandena är hämtade ifrån.

\section{Resultat}

\section{Presentation av gruppdeltagarna}

Gruppen kvinnor som bodde på landsbygden (KL) bestod av fyra kvinnor i åldern 61-68, ingen av dem förvärvsarbetade. De hade kortare utbildning än kvinnorna i storstadsområdet, som hade högskoleutbildning, två av dem hade arbetat inom omsorgen och två som laboratorieassistenter, en av dem hade varit hemmafru under många år.

Gruppen kvinnor som bodde i storstadsområdet (KS) bestod av fem kvinnor i åldern 66-70, ingen av dem förvärvsarbetade. De hade högskoleutbildning och tre av dem hade varit egna företagare och två hade arbetat som socionom respektive lärare.

Gruppen män som bodde på landsbygden (ML) bestod av fem män i åldern 63-69, tre av dem förvärvsarbetade fortfarande och två hade gått i pension. De hade kortare utbildning än männen i storstadsområdet och de arbetade eller hade arbetat inom tillverkningsindustrin, med fastighetsskötsel och på båtklubb.

Gruppen män som bodde i storstadsområdet (MS) bestod av sex män i åldern 63-65, fyra av dem förvärvsarbetade fortfa- rande och två hade gått i pension. De hade högskoleutbildning och de hade arbetat med marknadsföring, ekonomi och utbildningsfrågor.

\section{Tema 1: Hur deltagarna beskrev alkoholens roll under deras uppväxt}

Deltagarna var födda 1938-1949, de växte alltså upp under 40- och 50-talet. Fem av deltagarna hade växt upp i nyktra hem. Av dessa var det en som hade växt upp i ett religiöst hem, en som hade en far som var med i godtemplarordern och en hade en far som slutat dricka innan han bildade familj: "Farsan söp väldigt innan han träffade morsan. Hon satte ultimatum; inget giftermål om han inte la ner spriten?" (ML) Lika många beskrev sina föräldrars konsumtion som synnerligen måttlig, det dracks endast vid vissa festliga tillfällen.

Några beskrev moralismen kring drickande: "De som drack var noga med att det inte skulle synas, min far tog med sig portföljen till systemet och lindade in flaskan noga. De ville inte att de "religiösa" skulle veta." (ML) "De vuxna varnade för gubbarna i pilsnerbacken"(MS). Flera av deltagarna definierade sitt möte med alkoholen i uppväxten som okomplicerat. Föräldrarna och de vuxna släktingarna drack sprit när det var kalas, föräldrarna tog en snaps till söndagsmiddagen eller vin när det var gäster hemma. En kvinna hade våldsamma och negativa erfarenheter från uppväxten med en far som hon definierade som "alkoholist".

Analytisk kommentar: De två konstruk- 
tioner som står mot varandra i detta tema är den moralistiska och/eller nyktra konstruktionen och den tillåtande konstruktionen av uppväxten. I den förra uttrycks att de vuxna aktivt tagit ställning mot alkoholen, alkoholen sågs som ett problem. I den andra konstruktionen är alkoholen ett ickeproblem, man hade vuxit upp i hem där det var tillåtet att konsumera alkohol, ibland i måttliga mängder, men det var tillåtet.

\section{Tema 2: Hur deltagarna beskrev sin alkoholdebut}

Kvinnorna på landsbygden talade om sin alkoholdebut som odramatisk. Det var män inblandade $i$ allas redogörelser; en kvinna var med i en filmklubb där de lite äldre killarna bjöd på vin. En kvinna bodde hos sin äldre bror i staden och han lärde henne dricka öl och en annan kvinna träffade sin man när hon var ung och han drack ganska mycket och det hände att hon själv var ganska berusad ibland. Alla kvinnorna i storstadsområdet berättade utförligt om sin alkoholdebut, de beskrev den som att de gjorde något otillåtet. Män hade ingen framträdande roll i deras berättelser. De handlade om att gå på systemet, trots att fina flickor inte skulle göra det, att "råka" dricka drinkar på morbroderns hotell $i$ tron att det var läsk eller att gömma en vinflaska i systerns rum och dricka ganska mycket under tonåren. Männen, i båda grupperna, hade haft ganska dramatiska "första gången" upplevelser. De hade druckit för mycket starksprit och varit kraftigt berusade.

Några av deltagarna drack sedan inte på ett par år efter alkoholdebuten. Ett par av männen hade under långa perioder haft rollen som chaufför åt sina kompisar, vilket gjorde att de "slapp" dricka. Någon for till USA och bodde i ett helnyktert hem. Andra fortsatte att dricka efter debuten. Ett par av deltagarna beskrev den tiden som att de då drack för mycket, att drickandet fick negativa konsekvenser.

Deltagarnas liv stabiliserades vid 20 års ålder och det var flera som bildade familj tidigt. Hur detta påverkade alkoholkonsumtionen uttrycktes av en man i MLgruppen: "Fruntimmer har en lugnande inverkan!" De kvinnor som bildat familj sa att de drack måttligt under denna period, kanske drack de något på lördagskvällen. "Alltså man drack inte på den tiden när ungarna var små, man hade inte råd att ha sådana vanor." En kvinna, som definierade sin nuvarande alkoholkonsumtion som att hon dricker för mycket, problematiserade även tiden som ung vuxen: "Jag tror att vi var väldigt berusade, ofta."

Analytisk kommentar: Deltagarna skapar under detta tema i samtalen en bild av sig själva, sin identitet, inför de andra och för sig själva. De två konstruktioner som här står mot varandra är männens och kvinnornas beskrivningar av alkoholdebuten. Männen beskrev den som en rite de passage, något som kan sägas ingå i deras vuxenblivande. Kvinnornas konstruktioner var att de gjorde något förbjudet, något som inte stämde med deras identitet som "den fina flickan", eller som något odramatiskt. Den underliggande poängen är att det är möjligt för en man att berätta om hur han som ung drack sig redlöst berusad, det kunde inte en kvinna göra. 


\section{Tema 3: Hur deltagarna definierade sitt nuvarande alkoholbruk}

Ingen av deltagarna i fokusgrupperna definierade sig som nykterist. Men i alla grupper, utom i MS-gruppen, var det en eller ett par som definierade sin alkoholkonsumtion som att de drack lite. En kvinna i KSgruppen sa att hon druckit lite hela livet. Två kvinnor i KL-gruppen sa att deras livssituation gjorde att de numera drack måttligt. Den ena hade varit med om tragiska alkoholrelaterade händelser i familjen och därför drack hon numera sparsamt. Den andra kvinnan levde ensam och hon tyckte inte att det var roligt att dricka utan sällskap:

Då ska man ställa sig och laga mat också, det är inte så gott till falukorv eller pannkaka. Nej, det känns... men jag blir gärna bjuden. Men man blir inte bjuden på några parmiddagar när man är ensam heller. Det vart slut med det. Vi var ett ganska stort gäng som träffades regelbundet, men sen, sen har det inte blivit...(KL)

I alla fyra grupperna fanns det två eller fler deltagare som definierade sitt alkoholbruk som en del i en livsnjutning:

Tänk vitt vin när det är varmt ute, det är inte dumt. Om man åker till Stockholm med gubben, går ut och äter, det är klart man vill havin. Absolut! (KL)

För mig har det ändrats, kan säga att jag inte har några hämningar alls när det gäller att dricka. Är jag sugen på ett ta ett glas vin, när klockan är elva på dagen och det är några speciella omständigheter, så gör jag det. Jag tänker inte att man inte ska dricka på förmiddagen, att man inte ska dricka för sent på kvällen, att man inte ska dricka ditten och inte datten. Jag säger inte det för att jag dricker mycket, men jag dricker, jag har lust när jag har lust.// Det ändrades efter 40 någonting. Fast nu när man är pensionär är man ju ännu friare, jag menar att när man jobbar så tar man inte ett glas vin till lunchen. Men det kan jag göra nu.(KS)

Efter en hel dag i skogen (under älgjakten) där det är kallt och ruggigt, är det gott med en eller två snapsar och något vinglas. Det är semester! Man går och lägger sig tidigt, ska upp klockan fem nästa morgon och köra bil och då måste man vara fräsch.(ML)

I MS-gruppen definierade alla sitt eget alkoholbruk som en del av en livsnjutning: " Som pensionär dricker man oftare fast kanske inte lika mycket varje gång. Man har ju inga krav, har inte så bråttom i säng. Man har flera tillfällen att äta gott och det handlar inte om berusning längre." (MS)

Tre av männen i ML-gruppen redogjorde för sitt alkoholbruk med någon form av ursäkt. De problematiserade inte sin alkoholkonsumtion, men de moraliserade över sitt eget och andras drickande. "Jag har ju konsumerat en del öl, och gör fortfarande, det måste jag erkänna. När helgen kommer blir det faktiskt så." En man talade inte om sitt eget alkoholbruk. På direkta frågor om den egna konsumtionen eller positiva erfarenheter av alkohol moraliserade han istället över andras drickande: "När jag var på 
jobbet brukade vi ha någon tillställning och det var nästan alltid någon som gick över styr." (ML)

En deltagare definierar sin alkoholkonsumtion som att hon dricker för mycket, hon beskrev sin konsumtion som problematisk:

Jagär nog den i sällskapet som dricker mest. Inte omåttligt, men när ni säger box; Herre gud, jag tar ett glas vin ur den boxen varenda kväll! Ibland tänker jag, en flaska den räcker ett par dagar. Lite så att jag fär skärpa mig själv, jag får tänka. Det är inte så att jag rusar in till grannen och knycker i deras källare. Men jag kan tänka; det här är inte bra! Det är någonting - beroende kallar de det. Det är oerhört sällsynt att jag blir berusad, tror jag. Men ändå så kan jag känna att det finns... Jag tar alltid bilen nu när jag åker bort, av den anledningen, ofta. För att jag ska slippa...(KS)

Analytisk kommentar: Den dominerande konstruktionen i detta tema är att se sin alkoholkonsumtion som en del av en livsnjutning, men man poängterar samtidigt att man är en ansvarsfull människa. Efter pensioneringen, när man inte längre har samma ansvar, kan man dricka oftare. Det implicita budskapet är att när man förvärvsarbetade drack man inte lika ofta. Enligt denna konstruktion kan man också kontrollera sitt drickande, som en ansvarsfull person dricker man inte för mycket om man till exempel ska köra bil dagen efter.

De deltagare som definierar sin alkoholkonsumtion som att de dricker lite, förklarar denna position i förhållande till den dominerande konstruktionen, de rättfärdi- gar sina handlingar. Några andra deltagare argumenterar, utan större framgång, mot den dominerande konstruktionen. Den deltagare som definierar sin konsumtion som att hon dricker för mycket, gör det i relation till den dominerande konstruktionen. Hon har inte den kontrollen som en ansvarsfull person bör ha.

\section{Tema 4: Gränserna mellan acceptabelt och oacceptabelt alkoholbruk}

Deltagarnas redogörelser för lyckade dryckessituationer kan beskrivas som att alkoholen, i rätt sammanhang, utgjorde en kontrollerad guldkant i tillvaron. Alkoholens roll som markör var viktig, men det var lika viktigt att man hade roligt eller trevligt tillsammans med andra och att inget gick över styr. Exempel som gavs (KL) var ett trevligt bröllop, gästerna drack lagom mycket och ingen behövde tas om hand på grund av att hon eller han drack för mycket. Ett annat exempel (KS) var tre väninnor som ätit middag på restaurang, de delade på en flaska gott vin och det gjorde kvällen lite lyxigare. Någon påpekade att han (ML) blivit mer kräsen med åren, det skulle vara god mat och goda viner. Midsommar och jul brukade vara lyckade dryckessituationer. "Efter en jättehård segling, man ankrar och tar en kall öl. Det slår det mesta!" (MS) Likaså var älgjakten, som nämnts ovan, ett sammanhang där en man upplevt lyckade dryckessituationer. En kvinna (KL) menade att en vinare tillsammans med maken på fredagskvällen, eller på utlandssemestern, var trevligt nu när barnen var vuxna. 
Deltagarna menade att berusningen i sig inte var eftersträvansvärd. Men känslan skulle vara lite speciell, men den kunde också komma av situationen, ett vackert dukat bord till exempel. Alkoholen skulle göra att man kände sig på ett annat sätt; lite snällare, gladare, att något släppte eller att man blev avslappnad. Det optimala var "salongsberusning", berusningen skulle bara höja stämningen.

I dessa lyckade dryckessituationer kan alkoholen sägas vara en viktig markör för att situationen var lyckad. Men alkoholens betydelse tonades ner.

Deltagarna beskrev även situationer, eller sammanhang, som kan betraktas som neutrala eller till och med lite tråkiga, att de kan få en förhöjning om man också dricker alkohol.

En sådan situation, som diskuterades bland deltagarna, var att dricka ensam. De beskrev inte detta med att dricka utan sällskap som en lyckad eller misslyckad dryckessituation, utan som en gränsfråga för vad som var acceptabelt eller oacceptabelt beteende. I KL-gruppen var de ense om att man helst ska ha sällskap när man dricker alkohol. I ML-gruppen talade de inte om huruvida de själva drack utan sällskap, men de uttryckte ett avståndstagande mot ett sådant beteende när de diskuterade en bild på en man som satt ensam och drack vin: "Han har bekymmer? Den frånskilde mannen som dränker sorger?"

En av männen i MS-gruppen sa att han inte kunde tänka sig att dricka ensam, samtidigt bad han lite om ursäkt för detta ställningstagande: "Kanske en moralgrej, men jag skulle aldrig dricka för mig själv, max en öl. Öppna en pava och sitta själv, det finns inte på kartan?" En annan man i gruppen sa att han ändrat sitt beteende: "Jag har inte gjort det tidigare, någonsin, men förra året jobbade jag ensam i Göteborg, då köpte jag en flaska vin och tog ett par glas till middagen, det har jag aldrig gjort förut." En av männen var fortfarande yrkesverksam: "I veckorna är jag så fruktansvärt trött, så det är otänkbart. Men till helgerna, ute med båten, gärna en whiskey." De tre övriga i gruppen sa att de kunde ta sig en whiskey, eller en stor starköl efter bastun eller en dry Martini till matlagningen. I KS-gruppen tyckte alla att det var acceptabelt att dricka utan sällskap. Någon använde vin som måltidsdryck och någon tog gärna en irish coffee när hon såg sitt favoritprogram på TV. "Jag tror att det är efter pensioneringen som jag har det här förhållandet som ni pratar om (att dricka ensam), jag satt inte och drack vin till maten tidigare."

Deltagarna intog båda ståndpunkterna oavsett om de levde ensamma eller i parförhållanden. Det var snarare så att de som bodde på landsbygden tyckte att det var oacceptabelt att dricka utan sällskap, medan de som bodde i storstadsområdet i större utsträckning ansåg att det var acceptabelt. Men det var något som hade förändrats på senare år, ett tidigare moraliskt förkastligt beteende var nu mer accepterat bland storstadsborna.

Deltagarna i samtliga grupper tyckte att de med åren lärt sig att handskas med alkoholen. Erfarenheterna av egna oacceptabla, misslyckade dryckessituationer låg längre tillbaks i tiden. "De flesta man umgås med är så garvade, de håller kontrollen"(MS). Ibland kunde det bli lite misslyckat för att man var trött eller hungrig, och undantags- 
vis kunde det även numera hända att det blev för mycket:

Våra sommargrannar hade en tradition när man gick runt till varandra och då skulle det bjudas ordentligt. Då hamnar man i en situation när man fär lova att dricka ett glas whiskey, och inte ett litet glas. Då kan man... man måste ju dricka, det hör till(MS).

Men en alltför hög grad av berusning ledde till en helt misslyckad dryckessituation, det fördärvade stämningen. "Om det spårar ur, då är det alkoholens fel, berusningen kan göra att kontroll och hänsyn försvinner" (KS).

En av kvinnorna i KS-gruppen utgjorde ett undantag, hon tyckte att hennes egen alkoholkonsumtion hade varit och var oacceptabel. Hon hade flera exempel på när hon druckit ett eller två glas för mycket. Hon brukade prata för mycket, eller prata om fel saker, och hon brukade bli tillsagd. "Då blir jag medveten om det nästa dag att jag naturligtvis inte borde ha druckit det där sista glaset, eller de där två glasen. Då har jag tappat lite kontrollen, då är det misslyckat" (KS). Denna kvinna problematiserade sin egen alkoholkonsumtion, men hon hade samma uppfattning som de andra i gruppen om var gränserna går för en acceptabel alkoholkonsumtion.

De andra deltagarna beskrev andra personers alkoholkonsumtion när de talade om oacceptabla dryckessituationer. Om någon i ett sällskap blev påtagligt berusad kunde man sitta på spänn och undra hur det skulle sluta. De tog upp erfarenheter av bekanta som inte hade haft förmågan att kontrollera sitt drickande.
Alkoholens roll tonades ner, eller snarare undervärderades, när det handlade om lyckade situationer, medan dess betydelse snarare övervärderades när en dryckessituation definierades som misslyckad. Deltagarna beskrev en tydlig gräns för det acceptabla; man får inte skämma ut sig genom att dricka för mycket! "Jag har nog varit kontrollerande mot mig själv, jag har aldrig skämt ut mig på något sätt, absolut inte?" (KL). Samtidigt var det några uttalanden som pekade på en utveckling mot allt färre alkoholfria tillfällen i umgängeslivet: "När man kommer hem till folk, inte dricker man kaffe, oftast ett glas vin" (MS).

Men det är något jag reagerar på och det är...vi är ett gäng på tio stycken. När vi träffas är det aldrig att alla är nyktra. Det ska allid fram whisky och några vinglas. Det är lite knepigt egentligen. Vi är några familjer som träffas och det är alltid så. Jag menar inte att vi dricker massor, det är under ordnade former, men... (ML)

Analytisk kommentar: I detta tema framträder identitetsskapandet ännu tydligare. I samtalen kring en lyckad dryckessituation kan deltagarna skapa en mer detaljerad bild av sig själva: detta är jag! Den dominerande konstruktionen är en detaljrik beskrivning av en guldkantad tillvaro, där alkoholen är en viktig markör för en social gemenskap. Det som rubbar denna konstruktion är att flera deltagare även ser det som acceptabelt att dricka utan en social gemenskap, visserligen under kontroll men utan sällskap. Den konflikt som blir tydlig leder till förhandlingar huruvida detta är acceptabelt eller inte, en process varigenom deltagarnas 
identitet får skarpare konturer. Är jag en person som dricker ensam?

I samtalen om oacceptabla dryckessituationer markeras gränsen för den egna identiteten; detta är inte jag! Några deltagare kan beskriva situationer när de själva trätt över denna gräns, men det var för länge sedan, idag vet de hur de ska kontrollera sin alkoholkonsumtion. Men det dominerande är utsagor om andra, andra som förstör den sociala gemenskapen. Den identitet man skapar om sig själv är att en person vet var gränsen går och som därför inte behöver skämmas över sin konsumtion och sitt uppträdande.

Ett påpekande som ifrågasätter den rådande konstruktionen är att alkoholen tenderar att inte bara vara en viktig markör, utan en nödvändig markör för den sociala gemenskapen. Detta påpekande ger vid handen att det är möjligt med ett annat beteende, något att förhandla om i fortsatta samtal som handlar om alkoholkonsumtion.

\section{Tema 5: Andra människors sätt att handskas med alkohol}

När deltagarna granskade bilderna som illustrerade olika dryckessituationer, vägde de samman en rad faktorer, diskuterade dem och värderade situationen som en acceptabel eller oacceptabel dryckessituation. Några få bilder definierade alla deltagare som acceptabla dryckessituationer och de kunde tänka sig att själva vara med i en liknande situation. En bild föreställde ett par i 30 års åldern som satt på en uteservering med varsitt glas vin, den tyckte alla såg trevlig ut. Flera bilder ansåg samtliga deltagare illustrera helt igenom misslyckade dryckessituationer. De kunde inte tänka sig själva i den situation som bilden illustrerade. Om bilden visade ungdomar kunde de möjligen tänka sig att de varit med om något liknande när de själva var i den åldern."Usch, det här är finlandsbåten, det kan aldrig gå bra, de här två är bakfulla till max dagen därpå!" (KL).

Flera bilder genererade kommentarer om huruvida det lurade en fara, om en till synes lyckad dryckessituation skulle kunna gå över styr. "Alla dricker öl, men det ser inte oroväckande ut // det ser rätt stillsamt ut, än så länge" (MS). På min fråga om vad de trodde skulle hända efter fototillfället gav de svar som: "Det kan bli ett par tre stycken som flipprar ur där, i alla fall minst en" (KS).

Bilder som väckte diskussioner, och där deltagarna hade olika meningar, var bilder som visade dryckessituationer där barn var närvarande. Samma bild gav motstridiga kommentarer som; "En ordinär bild, en fredagskväll, man tänder ljus och tar en flaska vin, har en gryta och ljus på bordet, sen går ungarna och lägger sig och mamma och pappa har det mysigt" (KL). "Känns inte helt rätt för mig, de sitter alltså och dricker vin och tar med ungarna, man behöver inte göra det. Man kan vänta tills ungarna har gått och lagt sig" (ML).

När bilden föreställde en ensam människa då utlöste det, som tidigare nämnts, en diskussion om huruvida det var acceptabelt eller inte att dricka utan sällskap. När det var bilder på sällskap spelade åldern stor roll, var det endast ungdomar med på bilden dömdes dryckessituationen ut som 
oacceptabel eller så anades en fara, risken var stor att det skulle gå över styr.

Analytisk kommentar: Här dras gränsen mot det oacceptabla ännu skarpare. Det handlar inte bara om att förstöra en social gemenskap, det handlar om risk och fara. Deltagarna konstruerar bilden av andra människor, särskilt yngre, som de inte identifierar sig med. Den underliggande identitetskonstruktionen är: jag är inte som de?

\section{Helhetsanalys av samtliga teman}

Den dominerande identitetskonstruktionen är att deltagarna är livsnjutare som använder alkoholen för att förgylla den sociala samvaron. I analysen framkommer dock att alkoholkonsumtion är ett moraliskt impregnerat ämne att tala om. Den till synes tillåtande konstruktionen är omgärdad av gränser för det moraliskt lämpliga beteendet, gränser för vad som är rätt och vad som är fel. Den stränga moral som tidigare omgärdade alkoholkonsumtionen kan sägas ha flyttat från det omgivande samhället till den enskilda individen (Room 1997). Deltagarna gör skillnad mellan kvinnors och mäns alkoholdebut, de poängterar ansvar och kontroll (jfr Haarni \& Hautamäki 2010) och de månar om den sociala gemenskapen. När de berättar om hur de definierar sin egen alkoholkonsumtion beskriver de sin identitet, men i dessa konstruktioner ligger även möjligheten till ett motsatt beteende. Om det är rätt att vara ansvarsfull är det också fel att vara ansvarslös, om alkoholen är en guldkant som förgyller den sociala samvaron kan den också vara till fördärv om man inte har kontrollen och dricker med måtta. Detta uttrycks explicit när de kommer till talet om andra människors alkoholvanor.

Deltagarna konstruerar olika identiteter, deras erfarenheter och deras livssituation är faktorer som påverkar deras identitetsskapande men de relateras till den rådande alkoholkulturen (jfr Tolvanen 1998; Jung 2010). Den rådande alkoholkulturen ifrågasätts också, huruvida det är rätt eller fel att alkoholen i många sociala sammanhang har blivit ett krav.

Fenomenet att det kan vara förenligt med god moral att dricka ensam finns inte med i Abrahamsons (2009) studie, där var alkoholkonsumtion något som endast sker $\mathrm{i}$ samvaro med andra människor. Även unga med mycket mer omfattande alkoholvanor ser det som oacceptabelt att dricka ensam (Abrahamson 2004). Att man i föreliggande studie i denna åldersgrupp diskuterade detta, torde visa på en pågående förskjutning av gränsen för det acceptabla. Målet för det acceptabla drickandet måste inte längre bara vara att upprätthålla den sociala samvaron.

I samtalen fanns inget tal utifrån hälsoaspekten, vare sig positivt eller negativt (jfr Immonen et al. 2011). Det kan tolkas som att hälsoaspekten inte var till någon hjälp i konstruktionen av den egna identiteten $\mathrm{i}$ relation till alkoholkonsumtionen.

\section{Sammanfattande diskussion}

Det mest centrala i denna analys av fokusgruppssamtalen är att deltagarna utgår från en gemensam kulturell förståelseram när 
de samtalar om sin alkoholkonsumtion. När de tillsammans skapar och omskapar denna ram är det utifrån en moralisk dimension, samtalen handlar om vad som är hedervärt och vad som är klandervärt. I samtalen skapar de enskilda deltagarna sin egen identitet i relation till den gemensamma ramen. Den underförstådda fråga deltagarna ställer sig är: Vem är jag?

De tolkningar som gjorts av samtalen är exempel på möjliga tolkningar. Med andra utgångspunkter skulle tolkningarna kunna bli andra. Analysen är dock i sin helhet i linje med tidigare forskning. Tidigare studier har använt individuella intervjuer, livsberättelser och enkäter som datainsamlingsmetod, medan denna studie har haft fokusgrupper som insamlingsmetod. Fördelen med denna metod är att materialet har blivit rikt och framförallt att förhandlingarna mellan deltagarna har kunnat fångas. Samtalen illustrerar hur vi skapas och omskapas i samspelet med andra människor.

Deltagarna valdes ut utifrån kön, bostadsort och utbildning för att försöka fånga en bred grupp 60-70-åringar. För att jämföra de olika grupperna med varandra krävs ett större underlag. En metodologisk nackdel är även att materialet är förhållandevis litet, det har ändå gett en möjlighet att peka på några av de aspekter som lyfts fram.

\section{Referenser}

Abrahamson, M. (2004). "When I drank too much"- young people in their 20s tell their stories. Nordisk alkohol. \& narkotikatidskrift, 21 (English supplement): 63-78.

Abrahamson, M. (2009). Äldres värderingar och ideal i skrivaruppropet "Alkoholen i mitt liv". Nordisk alkohol- \& narkotikatidskrift, 26 (5) 439-461.

Adelswärd, M. (1997). Berättelser från älgpasset. Om metoder för att analysera jaktberättelsers struktur, poäng och sensmoral. I: Hydén, L-C \& Hydén, M (red.) Att studera berättelser. Stockholm: Liber.

Billinger, K. (2000). Få dem att vilja. Motivationsarbete inom tvångsvården av vuxna missbrukare. Akademisk avhandling. Stockholm: Rapport i socialt arbete $\mathrm{nr} 95$.

Blazer, D.G. \& Wu, L-T. (2009). The epidemiology of at-risk and binge drinking among middle-aged and elderly community adults: National survey on drug use and health. Amer- ican journal of psychiatry, 166 (10) 1162-1169.

Elster, J. \& Skog, O-J. (1999). Getting Hooked. Rationality and Addiction. Cambridge: Cambridge University Press.

Haarni, I. \& Hautamäki, L. (2010). Life experience and alcohol: 60-70-year-olds'relationship to alcohol in theme interviews. Nordic studies on alcohol and drugs, Vol. 27, 241-258.

Hübner, L. (2009). Allmänhetens uppfattningar om alkohol och alkoholpolitik. I: Billinger, K. \& Hübner, L. (red.) Alkohol och droger - Samhällsvetenskapliga perspektiv. Malmö: Gleerups.

Immonen, S., Valvanne, J. \& Pitkälä, K. (2011). Older adults'own reasoning for their alcohol consumption. International Journal of Geriatric Psychiatry, 26:11, 1169-1176.

Jung, J. (2010). Alcohol, other drugs, and behavior. Psychological research perspectives. London: Sage.

Kaskutas, L.A., Achmidt L.A., Weisner, C. \& Greenfield, K. (2000). Collecting valid data 
from community sources - methods for evaluation policy changes in alcohol services. Addiction, 95 (Supplement 3): 329-345.

Kvale, S. \& Brinkmann, S. (2009). Den kvalitativa forskningsintervjun. Lund: Studentlitteratur.

Lieblich, A., Tuval-Mashiach, R. \& Zilber, T. (1998). Narrative research - Reading, analysis and interpretation. Thousand Oaks: SAGE Publications.

Moore, A.A., Gould, R., Reuben, D., Greendale, G.A., Carter, M.K., Zhou, K., \& Karlamanga, A. (2005). Longitudinal patterns and predictors of alcohol consumption in the United States. American Journal of Public Health, 95: 458-464.

Socialstyrelsen (2012). Lägesrapport 2012. Tillståndet och utvecklingen inom hälso- och sjukvården och socialtjänsten. Socialstyrelsen: Stockholm.

Room, R. (1997). Alcohol, the individual and society. What history teaches us. Addiction, 92 (Supplement 1):7-11.
Tigerstedt, C., Simonen, J. \& Törrönen, J. (2010). Finish drinking habits in the light of group interviews. I: Beccaria, F. (red.) Alcohol and generations - Changes in style and changing styles in Italy and Finland. Roma: Carroci editore.

Tolvanen, E. (1998). I and others: alcohol use among older people as a social and cultural phenomenon. Aging and Society, 18: 563-583.

Tolvanen, E. \& Jylhä, M. (2005). Alcohol in life story interviews with Finnish people aged 90 or over: stories of gendered morality. Journal of Aging Studies, 19: 419-435.

Valkonen, T. \& Kauppinen, T. (2005). Märkä ja nuorena nukkuva sukupolvi? Teoksessa: Karisto, A (toim.) Suuret ikäloukat. Tempee: Vastapaino, 334-346.

Wetherell, M. \& Maybin, J. (1998). Det "distribuerade" jaget - ett konstruktionistiskt perspektiv. I: Stevens, R. (red.) Att förstå människor. Lund: Studentlitteratur. 


\section{Summary}

\section{Sixty-to-seventy-year-olds talk about their alcohol consumption}

The purpose of the study is to shed light on how people in their sixties and seventies, in four different groups, talk about their relationship to alcohol, how they look at the boundaries between what is acceptable and unacceptable drinking. The methodology used for data collection was focus group interviews. In order to capture a broad range of people, the groups differed according to gender, education and place of residence. The result shows that participants' drinking habits varied and they defined their alcohol consumption in different ways. The most common repertoire was talking about alcohol consumption as part of pleasure in life, but a few said that they did not drink so much; one said that she drank too much; none of the participants was a total abstainer. Alcohol was an important marker to show that social relations were successful, but several of the participants also considered that it was acceptable to drink alone, without any social interaction. Opinions differed, however, as to whether this was acceptable or not. With one exception they all thought that they had learnt through life how to control their consumption. None of the participants talked about their alcohol consumption from a health perspective, whether positive or negative. A possible interpretation of this is that the health aspect was not helpful in the search for what is considered acceptable alcohol consumption. 